\title{
Women Learning in Garment Work: Solidarity and Sociality
}

by Tara Fenwick, University of British Columbia

\begin{abstract}
This article explores processes and possibilities for critical learning in the workplace, with a focus on workers labouring in what are often exploitive and dehumanizing conditions. The argument is based on a study of work-life learning of women, mostly new immigrants, employed long-term at an Alberta garment manufacturing plant. It is argued that their negotiations of work conditions are nested in various areas of learning associated with everyday practices, small communities, labour organizing processes, and English learning classes. These areas are argued to have generated forms of solidarity emerging through learning about sociality, resistance, and personal worth. These solidarities appear to be configured by energies of both transformation and reproduction that are threaded together and generated simultaneously as women learned to survive within the system while supporting one another in a vital interdependent social network. The discussion explores how these dynamics unfolded, and their effects on how different women positioned themselves and their knowledge.
\end{abstract}

The garment industry has historically produced a job ghetto for women through forces of class, gender, ethnicity and family (Ng, 2002a; Steedman, 1997; Tyler, 1995). The unsanitary, crowded and dreadfully hot (hence ‘sweatshop') conditions of women's garment work, documented as abysmal in the late $19^{\text {th }}$ and early $20^{\text {th }}$ centuries by historians (Levine, 1924; Dubinsky, 1977; Tyler, 1995), have continued to be notoriously difficult in the second half of the $20^{\text {th }}$ century: highly fragmented and mechanized piece work, low wages, emphasis on speed, repetitive strain injuries, and almost no personal control over the work activity (Steedman, 1997). New immigrants in particular have fuelled these sweatshops, beginning with the European and especially Jewish settlers pouring into the US northeast cities in the 1880s (Levine, 1924, Tyler, 1995), and continuing with waves of immigration throughout the $20^{\text {th }}$ century in US and Canada, providing cheap labour and suffering systemic racism, long hours and precarious employment arrangements.

What of the learning of garment workers? For some unions, such as the International Ladies Garment Workers Union (ILGWU), workers' education was a priority particularly in the first half of the $20^{\text {th }}$ century promoting not only political participation but also intellectual engagement, social communion, athletic activity and 
artistic expression (Wolensky, 1996). In fact according to Levine (1924) the 1909-10

New York uprising of women's shirtwaist workers (the largest women's strike in

America) succeeded because of a collective spirit of mutual devotion and self-sacrifice:

solidarity, learned through struggle. Dubinsky, who built ILGWU into a powerful activist network of social change that established many hallmarks of American unionism (Tyler, 1977), placed workers' learning firmly at the center of the union's objectives. For him, class struggle was a great classroom in which workers could learn how to be an effective collective voice in the workplace, the nation and the world (Dubinsky, 1977).

But in the latter decades of the $20^{\text {th }}$ century and despite the legacy of activist learning promoted by the unions, garment work in the US migrated south and eventually overseas to unregulated sweatshops: thousands of garment workers lost their jobs (Wolensky, Wolensky \& Wolensky, 2002). Similar dynamics attacked the Canadian garment industry, and as $\mathrm{Ng}$ (1999) reports, unemployed seamstresses drifted into home-based work. Where any consideration at all has been extended to garment workers' learning in recent decades, the focus has been upon increasing efficiency and coordination from the employers' standpoint, resulting in an emphasis on skill training $(\mathrm{Ng}, 2002 \mathrm{~b})$. Little information is available about learning from the workers' standpoint, and their informal collective and political learning is largely unacknowledged. So it is not surprising that we understand little about how garment workers learn to make sense of their work, or learn about their rights and how to negotiate these rights with employers and other workers - not only in relation to a job, but in relation to the work place and the larger society.

How do women learn to negotiate and survive the exploitive conditions of garment work? What, if any, forms of resistance or solidarity are possible in such environments, and how do women learn to participate in them? These questions guided part of a recent qualitative study that set out to examine the worklife and workplace learning of women employed in a large garment 
factory located in western Canada: the Great Western Garment company (GWG). The plant shut down in 2004 to move operations to Haiti. The intent of the study was to go beyond representations of women garment workers as passive victims, utterly subjugated by the mechanized organizing processes and gendered structures that were clearly present in their workplace. Drawing from an oral history approach, interviews were held with 26 women garment workers to explore, through their personal narratives of everyday activity, social relations and learning in the plant, how they made sense of their work and their identities, and how they positioned themselves in terms of recognizing and seeking to defend their rights as workers.

The first section of the article situates the argument within perspectives on critical learning and solidarity in the workplace, and the garment industry in Canada. The second section describes the research methods employed in the study. The third section presents findings related to women's learning, arguing that at least part of this learning can be understood as participating in fluid and complex forms of solidarity in garment work. The final section suggests implications for understanding women workers' learning to negotiate exploitive work through various overlapping forms of solidarity.

\section{LEARNING, GARMENT WORK, AND SOLIDARITY}

The perspective on learning in work adopted in this discussion is aligned with sociocultural conceptualizations (Fenwick, 2001; Sawchuk, 2003) that view learning as embedded in everyday practices and social relations. Learning itself is understood here to be an expansion of capacity, with focus on action that builds individual and collective agency, particularly to enhance workers' well-being and critical awareness of work structures, to foster more equitable structures, and to increase workers' control over their activity. In workplace contexts, practices and relations are structured by the object at which activity is directed, the division of labour 
comprising the work arrangements, the tools and technology mediating the activity, the perspectives and interactions of the actors, the cultural history of the activity system, and the contradictions the system embeds (Sawchuk, 2003). Most important, following the call of Howell, Carter and Schied (2002) for research focusing on learning experiences of (marginalized) women workers, the analysis centers on the narratives of the women themselves.

\section{Garment work in Canada}

$\mathrm{Ng}$ (1999) reported that workers in Canada's garment industry throughout the $20^{\text {th }}$ century traditionally have been mostly women, about half being new immigrants. $\mathrm{Ng}$, along with others (Gannage, 1999; Steedman, 1997; Vosko, 1993), has argued that in the garment industry in particular, the category of "immigrant women" has reinforced their classed and gendered position in providing cheap labour to the state in exploitive conditions. Repetitive strain injuries became common as new technologies in equipment and process were introduced to maximize production and minimize excess movement (Gannage, 1999). Steedman's (1997) large study of garment work in Canada concluded that the numbing work conditions, brutal piece-work pay structures and relative lack of employee benefits were also partly a result of agreements negotiated by men with men. Women were rarely included in bargaining their own collective rights.

Globalization brought a widespread closure of these plants in the 1990s, with a loss of 33,000 jobs in Canada between 1989-1993. Garment workers now are being forced into precarious employment as home-based workers or employees of small shops, dependent for their work on the unregulated "jobbers" that supply large distributors (Vosko, 1993). Studies have raised urgent concern over the resulting precarious contracts, low wages, isolation, and general exploitation of these women in this web of market relations that continue to oppress them $(\mathrm{Ng}$ ' 1999, 2002a,b; Mirchandani, Ng, Sangha, Rawlings, \& Coloma-Moya, 2002). Even in those 
plants that remained open in the 1990s, Livingstone and Sawchuk (with Clara Morgan) (2004, p. 224) claim that immigrant women workers were among the most disadvantaged in Canada.

Gendered work structures are inherent in this industry. Women in garment work typically receive lowest-paying, supposedly unskilled jobs - as sewing machine operators and pressers (Ng, 1999; Tyler, 1995). Bulk cloth cutting traditionally is men's work which is better paid, segregated in rooms apart from the noisy sewing machines, and allowed more physical freedom of movement than machine sewing. Conventional notions of skill tends to rest on a hierarchy of capacities (from unskilled to semi-skilled to specialized skills) accorded economic value linked to perceptions of production priorities, cultural notions of useful work and global markets of supply and demand. Feminists have long called attention to gendered determinations of skill that persist in ways that undervalue, even ignore, women's complex strategies and practices in so-called low skill work (Jackson, 1991; Probert, 1999). Arguably in garment work this fundamental lack of recognition of women 's skills not only sets their value and income at low levels, but also renders them effectively faceless and voiceless: they become interchangeable machine operators in a denial of their subjectivity, their personal knowledge and struggles.

\section{Solidarity, sociality and critical learning}

Given these conditions, the question of collective and 'critical' learning among such workers and the possibilities for their solidarity becomes particularly pertinent. Baldwin (1990) writes that solidarity emerges in a common experience of vulnerability, "a sense of community ... in the face of universally shared risk" (p. 34), and is necessary for workers to defend themselves against exploitive, alienating and numbing work conditions. As Thompson (1963) argued so passionately, a shared identity and commitment to the collective as well as a history emerges through workers' constant everyday struggle, sharing experiences and values in the midst of conflictual relations. The central issue is workers' own agency in an active process of 
continuously 'making' themselves ${ }^{1}$. In many iterations, solidarity combines emancipatory or critical learning with collective social action for transformation of both individuals' consciousness and work or social structures (Foley, 1999; Heaney 1996; Zacharakis-Jutz, 1993). Transformation in certain emancipatory conceptions tends to be positioned in opposition to reproduction, where learning functions to accommodate workers to exploitive, hierarchical structures, subjugating people and reproducing existing (inequitable) power relations. The perception is that if workers do not critically question these structures and work to resist them, they become assimilated and increasingly complicit in reproducing the very practices that oppress them. It is important to note the complexity and different manifestations of solidarity (Hodson, Welsh, Rieble, Jamisen, Sorenson, \& Creighton, 1993). For example, Sawchuk (2003) describes a form of 'solidaristic networks' among working people that generate emancipatory potential. Others found a form of solidarity emerging when immigrant women workers developed a collective identity and shared strategies for negotiating their lives as non-Englishspeaking immigrants (Church, Shragge, Fontan, \& Ng, 2000). Solidarity in these findings was not necessarily confined to workers engaging in social action to challenge their status.

Both learning and 'sociality' - interpersonal and collective social interaction - are arguably at the core of solidarity in its different possible forms. In debating the erosion of collectivism and the possible irrelevance of solidarity in new times of fluid capitalism and worker individualism, D’Art and Turner (2002) conclude the continuing importance and evidence of workers' critical learning and collective association for activism.

Organized labour historically has provided an important site to develop critical learning, to engage workers collectively in questioning mechanisms of control in the work process and reclaiming their agency and knowledge within labour divisions and capital structures (Dubinsky,

\footnotetext{
${ }^{1}$ I am indebted to an anonymous reviewer for reminding me to mention Thompson's influential work The Making of the English Working Class.
} 
1977). Workers' education, while providing liberal education and training for organizers, emphasized critical learning about the nature of work, capitalism, and the essential features of the broader class society (Taylor, 2001). For example at the Highlander Center founded by Myles Horton, US workers and labor organizers in the textile industries in the 1930s-1960s learned through group dialogue and democratic decision-making: participants critically explored their own concrete experiences in community and generated strategies for overcoming their oppression (Adams, 1975).

Workers' education eventually separated from 'mainstream' adult education in the late 19th century (Schied, 1993). However, a strong contingent of radical adult educators has debated the possibilities for critical pedagogy in the workplace. Educators aligned with Marxist perspectives view solidarity as a site for revolutionary social transformation, e.g. to abolish capitalism and liberate workers from exchange relations through participatory dialogues in dialectic with collective action (Allman, 2001; Holst, 2001). Like Horton, Cunningham (1993a) emphasizes 'counter-hegemonic struggle' through critical learning processes such as when groups critically reflect on their environment and ways to change it, thus exposing social bases of power.

However the workplace educator's role in such processes becomes complicated. Heaney (1996) cautions that professional educators themselves are part of the hegemony that workers need to resist, and Cunningham (1993b) says workplace educators must choose an allegiance to the organization or to workers: to maintain current power relationships or to contest them. Workers' learning is often directed towards increasing organizational productivity and capital. Even in critical education in the workplace, the struggle for control of workers' knowledge continues alongside concerns that emancipatory intents just get diluted in capitalist institutions (Fenwick, 2004). For example Mojab and Gorman (2003) show how women workers' social 
interactions, when reframed as a learning space $^{2}$, can be commodified by the organization as social capital to increase the surplus labour to be extracted from workers for profit.

These ideas suggest that sociality in the workplace produces knowledge that is either more transformative or more reproductive. Can both impulses occur together? Cunningham (1993a) reminds us that

If knowledge is socially produced, then knowledge can be produced by any group of people. Further, the way any group experiences the world, their culture, their contexts, will affect the way they see and name the world. (p.16)

The importance of workers' social learning has been long recognized, as Schied (1993) showed in documenting the importance of workers' clubs and other informal learning sites of the German-American working class in $19^{\text {th }}$-century Chicago. Dubinsky (1977) emphasized 'social unionism' to encourage social interaction in which intellectual engagement, health and political participation can flourish. In Welton's (1995) vision for “developmental” workplaces, social learning is the source for systemic change, through spaces fostering human connections, deliberations, and freedom to voice private desires. Sawchuk (2003) found that the learning of working-class women and men thrives in these informal or 'solidaristic' networks that arise within stable working-class communities. A certain mutuality and group orientation emerges in this sociality, forming not only knowledge production capacity but also emancipatory potential (Sawchuk, 2003). An example from immigrant workers is offered by Lee (2006), who used social network theory to analyse when critical learning occurs within sociality and when it does not. Thus workers' sociality can be envisioned as a site for solidaristic interconnections, identities, and spaces of creativity: this is important collective learning that sometimes may lead to resistance depending on the nature of the social ties and individuals' positions within them.

2 'Space' in this sense refers to an opening or forum, a geographic, temporal, political and/or social area of practice and knowledge. 
However, most analysts of critical social learning recognize the complexity and often contradictory nature of the process. One illustration is Mirchandani et al.'s (2002) study of immigrant women garment workers learning ICT (information communication technology) skills, showing that these women's learning was actually both reproductive and transformative, influenced of course by what women themselves wanted to learn. Another study of women's learning in marginalized work (Church et al., 2000) emphasized how their social interaction teaches strategies for both accommodating to the organization and forming a solidarity of collective identity, while redefining their selves. The question may be one of understanding the nature of sociality and under what circumstances sociality leads more to conforming with or to questioning work conditions and structure. The challenge might be exploring how and in what directions workers' sociality unfolds. Sometimes this sociality shapes the roots of workers' solidarity in various forms. Sometimes it promotes workers' alignment with capital and converts their learning into a commodified space of knowledge production. But usually movements of both reproductive and transformative learning exist together in the fluid forms of solidarity that emerge in everyday workers' interactions.

\section{STUDY DESIGN}

The study drew upon methods of oral history, an approach to exploring the past through individuals' personal memories of activities and events (Portelli, 1998). Oral history collects and preserves individuals' narrated experiences as a full life history, or as topical history such as experiences of the Great Depression, or as thematic history such as this study's exploration of women garment workers' work and learning at a particular plant. In the larger study from which this article selected one particular aspect for analysis, interviews were video-recorded with the intention of assembling these recollections of the plant history and storing them as archival material (along with historical photographs and other artifacts) in the Alberta Provincial Museum. The interviews resembled oral history in that individuals were asked to recall events 
and experiences over periods of time that in some cases were long past. However, the particular analysis for this article was focused on interpreting workers' experiences to discern critical learning patterns.

Oral historians are concerned with balancing the validity and accuracy of memory with respect for individuals' interpretations of events and their personal impact. Hoffman and Hoffman (1994) conclude that emotionally charged experiences such as 'firsts' and vivid or traumatic events are preserved and rehearsed by individuals, and should be treated as valuable 'archival memory':

They are memories which have been selected much as one makes a scrapbook of photographs, pasting in some and discarding others. They are memories which define the self and constitute the persona which one retains, the sense of identity over time. (Hoffman \& Hoffman, 1994, pp. 124-25)

Oral history is art, not science, maintain the Hoffmans, and the important thing is capturing the insights into the complex negotiations and strategies of everyday life offered by purposeful actors in ways that enrich broad analytic categories such as hegemony or transformation. Analytic methods for oral history resemble those employed in interpretive qualitative research, privileging the individual's meanings of experience and then layering and contrasting the various voices surrounding the topic or theme under investigation. In this study, individual's key stories were identified and organized by topic (reasons for taking the job, everyday conditions, strategies for surviving these, etc); then procedures of coding and categorizing themes across the stories, as described by Ely (1991), were employed to examine patterns of critical learning among these workers.

Twenty-six women garment workers who worked at GWG (Great Western Garment company) were interviewed through semi-structured conversations that explored their memories of everyday work and learning experiences at the GWG plant (see Table 1 for demographic details). Over two-thirds had been employed as new immigrants, and 12 could be classified as 
visible minorities. Almost half had worked at the plant for 20 years or more. Participants were recruited through open invitation in the plant and community networks. English was a second language for all except the eight Canadian-born participants. All participants were asked what language they preferred for their interview. All interviews were recorded and transcribed. All but eight Chinese participants requested English: these 8 interviews were conducted in Cantonese by one researcher and the tapes translated into English transcripts. Participants described the work activities and conditions as these changed over time, the nature of their relationships with other workers, their involvement in union and other educational experiences, their work challenges and the strategies they developed to meet these, and their responses to the plant closure. Most had been employed as sewing machine operators, though some had also been supervisors or had taken roles in union activities. Besides the garment workers, four workplace educators (all women) who had conducted English Language programs at the plant were interviewed.

As is usually the case with research interviews, issues of positionality and language can pose significant limitations to interviewee's comfort and openness. Some may have articulated what they thought interviewers wanted to hear, or what would best represent the plant in their views. Three interviews lasted only 30 minutes; others averaged about 50-60 minutes. The shorter interviews provided sufficient narrative from these individuals to satisfy the study purposes - to document personal memories of working and learning experiences at the plant at particular moments of history - but did not allow for much probing of participants' meanings of these events. This limitation required that our analysis proceed very carefully, examining certain memoirs in light of the others to compare and overlap remembered experiences of particular events. There was not sufficient data to analyse the very important issues of race and ethnicity at work here, or to conduct a full feminist analysis locating the women's narratives within the women's non-work lives and the overall structures of the organization. 
SOLIDARITIES: LEARNING SURVIVAL, SOCIALITY, AND PERSONAL WORTH

Great Western Garment company was opened in a large western Canadian city in 1911 to capitalize on the growing demand for durable workwear for miners and railway workers in that region. The plant was unionized since opening by the United Garment Workers of America (UGWA), switching to the United Food and Commercial Workers (UFCW) in 1984. Sewing machine operators were paid by the piece until the late 1980s, when the union finally negotiated a guaranteed wage system tied to a reasonable quota. GWG was the largest employer of new immigrants in western Canada for many years and workers were directly referred by settlement agencies, churches and family members. In 1987 GWG made available English-as-SecondLanguage programs, cost-shared with the provincial government, to help improve communication between workers and supervisors. GWG closed its Alberta plant in December 2004, throwing out of work over 475 employees.

Many workers had emigrated to Canada to escape repressive regimes and build better lives for their families. They had been referred to GWG for employment by their relatives and immigrant agencies. Most said they needed the income, were happy to find full-time employment whatever the conditions, and believed they had no other choice than GWG, given their lack of English: "Why did I go into the sewing factory? I immigrated. I felt I was a second class citizen, not much money, language problem. I work” (Xiaofang, 1.45).

Thus among the GWG workers interviewed for this study, there was a certain acceptance, even gratitude, associated with garment work. Their learning was primarily rooted in their everyday work: figuring out how to maximize their (piece-work) pay while negotiating interactions among workers, supervisors and union representatives. As well, learning was experienced through structured opportunities such as supervisory training and English language classes. Solidarity 
unfolded through women's everyday participation in networks, tools, operations and events such as union meetings at the GWG factory. Solidarity also emerged in educative spaces opened by the English-learning classes. The following sections discuss these themes in greater detail: learning survival skills in garment work, learning solidarity as close connection, learning solidarity through pockets of resistance, and learning solidarity through personal worth.

\section{Learning survival skills in garment work}

The numbing conditions of sewing machine work have been well-documented and thus will not be dwelt upon here. The interesting dynamic is how soon new workers overcame their resistance to these conditions to become part of the factory machine. Some may, of course, have refused to comply and subsequently departed. Once hired, a new worker was shown how to perform one particular procedure such as sewing a belt loop. (The making of one pair of jeans had been divided into over 60 discrete procedures.) She might continue this procedure for several years, until she was told to move to a new operation: one worker said she tacked jeans front to back for 35 years. Piles of pre-cut fabric were brought to women in pre-counted bundles, then quality-assessed and counted for wages by someone else. Workers had almost no control over the process and the repetition: "piece work is very dreary. It's very tiresome. You're doing the same thing over and over and over again ..." (Gioia, 1. 72). But clearly all had learned how to get through the day in difficult conditions, given that over half of the workers interviewed had remained at those same machines for over twenty years. Some women hired at GWG expressed initial surprise at these conditions of industrial assembly lines:

My first day at work was a revelation. All I could see was a sea of sewing machines. At each one a bent over operator was working as if her life depended on it. All the operators were women. No one was saying anything. (Eithne, 1. 180-83)

Everything was dark, the floor was dark, the walls were dark, there was no daylight, artificial light. You didn't get out of your chair. (Dorottya, 1. 93-94) 
You had no control, no control at all. You didn't even keep track of your own work, they told you what you did. It was all up to them. You had to trust they were honest. (Beulah, 1.)

I hated it, it was an awful place. I just couldn't be shut up like that, it was like being in jail almost. Because I was sitting at a, at a, at a machine. (Eithne, 1.224-26)

In GWG just as in the Ontario factories described by Livingstone, Sawchuk and Morgan (2003), speed defined the work because pay was tied directly to numbers of completed bundles. The most important skill in survival was to learn how to sew as fast as possible without hurting oneself or making mistakes: both meant losing wages. Seams judged inadequate had to be ripped out and re-sewn without compensation. Women described a balance one needed to acquire between maximum personal speed and minimum errors. This balance required skill and continuous self-monitoring, and women frequently noted their own performance in comparison to others.

Some of the women, they wouldn't even take time to go to the washroom. They were just givin' her, you know? (Terry, 1.47475)

One worker who sewed the GWG logo onto pockets demonstrated a technique that she developed of whirling rotation among three machines. Injuries, particularly repetitive strain but also accidents such as heavy industrial needles punched through fingers occurred, but workers tended to brush these aside:

I almost took this finger off because I got it caught in the guide and I - trying to go fast, you see, and the finger cut -- but I kept on working, they put bandage on it and that was about it (laughs). (Dorottya, 1.320-23)

Even after wage structures were changed in the late 1980s from piece-pay to quota incomes, speed seemed to frame the work. Women competed with one another to complete more bundles. Essentially, in learning how to concentrate upon sewing as fast and error-free as possible, they were learning to turn their bodies into machines feeding the mass assembly production. There wasn't time to lift one's head and look around at what was happening, nor 
question it. This is the numbing effect that worried the adult educators working with them:

"...you cannot afford to let your mind wander. And so the mind loses its ability to think"

(Catherine, 1. 895-896). Thus the initial surprise, even shock, that workers remembered feeling

when they first stepped into the factory soon evaporated as they learned to comply with the conditions and keep their heads down, focused on their seams.

\section{Learning solidarity as close connection}

Despite the competitive structures of piecework and isolation on individual noisy machines, strong social bonds formed among some workers. Many described a community of strategic learning and friendships forming a tacit solidarity outside the union-management and cultural polarities surrounding them. This sociality seemed linked to interconnection, that every person's success in maintaining the high speed/low error balance helped all to maximize their income:

Teamwork, everyone has to help each other. The team does that much then they tell you to work together.... For example I make clothes, and you done this, and someone appears the sewing machine. We all have to help each other, but we don't talk about it. (Nancy, $11.328-40$ )

Ethnic groups tended to forge close networks, too, recruiting each other's relatives and friends for work at GWG, and describing life "on the line" as social, marked by laughter, gossip, information sharing, and mutual support for the various difficulties faced by individuals:

I love working with [GWG]. I'm going to miss it a lot actually. Lots of friends .... In our line most of the woman are from my country. And we work together, it's a nice atmosphere. (Halina, 11. 185-200)

The plant's wide diversity of ethnic/linguistic language groups also may have fostered capabilities for peaceful co-existence and communicating and working across difference:

Working you have to learn right. You have to give into people. It's not that you do good and the other people doesn't do good - you have to help people. In my opinion, working there I learned a lot of life experiences. You can't, just because you know something, be 
proud, you have to go slowly so that everyone can follow you - together- then that is good. If you don't, like this, care for the factory - like, if the chicken dies then how can you have eggs to eat? (Mingzhu, 11. 555-572)

This understanding of interdependence may in part have resulted through the work structures, which linked every line member. When someone was sick the entire line's work speed, and thus pay, was affected. But beyond this, women seemed to view GWG as a space apart from their private struggles in family and cultural adjustment. Coffee and lunch breaks were taken at the same time and all together. Women said they sat in groups talking during these periods, sharing stories and strategies of everyday life: coping with schools and children's acculturation, supporting extended family, managing child care between double shifts, shortcuts to getting a drivers' license, or finding the best Chinese vegetables.

The intimate connections and sense of family were evident at the plant's closing, which most workers described as very sad - mostly for losing the fellowship of their community: "It was like suddenly the family, it was suddenly breaking up" (Gioia, 1. 422).

When I heard the plant was closing I was very upset, I was crying. Yeah, that was my second home, you know. I been educated, I been -- I know more, more, more things like ever I can have. (Lihua, 1.763-66)

The daily interweavings of sociality thus appeared to create close connections that fostered these women's collective identity and sense of personal pride, albeit coded in terms of material production, as well as building some solidarity among them that apparently overrode the forces of isolation and competition embedded in the work structures.

\section{Learning solidarity through pockets of resistance}

In conceptions of transformation, workplace solidarity is often expected to extend beyond sensing collective interdependence to self-clarity and agency: to challenge inequitable structures and struggle for greater control of work processes. Some of this learning was clearly visible at GWG, generated directly through everyday practice and union exposure, and indirectly through 
the English classes. This learning was expressed in pockets of resistance which, though isolated, nevertheless appeared to introduce seeds of possibility that alternatives exist and conditions can be questioned.

For some, union activities offered political learning about inequitable division of labor, worker rights, and the possibility for resistance.

I got involved in union because I wanted to help people, I mean, to make difference. To make difference in people's life. And to change things. The more you get involved the more you get the stuff for the people. We can have a vision. (Huahui, 11. 1296-99)

Being involved in the union it sure opens your eyes ... a lot of them that didn't even know they had rights . . they were kind of in their own little cocoon there and, and they weren't being taught a lot of stuff. . . As people learnt that they had more rights, they, they would stand up more to their supervisors... It was a learning process the whole time they were there and it was really good because then they would teach their friends... And people weren't afraid anymore. (Mirela, 11. 1040-48).

This shop steward evidently perceived the political learning to have spread among other workers. However while for some the union was a site for personal growth in leadership and political learning, others reported little interest in the union. As one woman explained, people were afraid of losing their jobs and didn't want to "rock the boat". Some experienced the union as exclusive (meetings were held in English, with Chinese translation introduced in the 1980s), with forced dues and mandatory attendance. One interviewee from China said she and her friends preferred a "moderate" or "middle way" to union challenge in any case, and were irritated at efforts to change structures they believed to be immutable: "They [white women] always want to ask for reform, but can't reform. So what can change? So, don't do it” (Hong, 1. 656). Yet the discourses of rights and challenge were in motion around such positions. Another woman, frustrated over lost wages waiting for the technician to fix the machines which often "break", said she decided to just learn how to fix the machine herself: 
The stupid sewing machine man screamed, but actually, he doesn't know how to fix it. Luckily he didn't scream at me or else I would have screamed at him to death! (Xiaofang, 1. 167-68)

At times, bubbles of collective action arose in everyday work when the women demonstrated real agency in asserting their rights even without union leadership in doing so. One instance was when thin material was introduced that kept bunching up in the machines, slowing the women's work and reducing their pay. Their complaints were ignored. One group suggested they shut off the power to the machines, and eventually convinced the rest to do it. The story was that the general manager came out to hear the problem, and agreed to pay the women by time until the technical problem was sorted out: "if we weren't so scared we would have realized that they couldn't fire us, all of us" (Daryna, 1. 641).

In another case women did walk out over pay cuts, without union leadership:

About 1970 they were going to cut us down from twelve cents a bundle to less. Lana Cardinal and I, because we did the same job, we were side by side, she says Are you gonna take that? and I says, well I gotta work. She says, well I gotta work too, I gotta son to look after, but I'm gonna walk out. Then she said, I think you and I should both walk out and leave them stranded. So this is what we did. (Boyka, 1l. 312-317)

Minimum wage jobs were more plentiful in Alberta at that time, and the two women apparently had no difficulty finding work as salesclerks before the company contacted them to ask them to return.

These instances illustrate how pockets of resistance can emerge through the "solidaristic networks" that build in everyday sociality. When such a close-knit group experiences particular stress or unfairness, and when they support one another in naming the problem and discussing possible action - particularly when at least one in the group has sufficient confidence to push the point - the group can rise in solidarity and resistance. This aligns with Lee's (2006) findings of critical learning among immigrant workers' social networks.

\section{Learning solidarity through personal worth}


One space where sociality was nourished, along with awareness of rights and tools to communicate these to management, were the English-learning classes. The process and complexities of these classes at GWG are analysed at length elsewhere (Author, in press), but their importance as sites that generated solidarity warrants some brief description here. These classes appeared to emulate sites of “communicative action” in Welton's (1995) terms.

According to both students and the instructors, the learning groups formed close relationships. Students who qualified to "graduate" preferred to keep coming to the classes. Individuals were recognized and their learning valued in ways they had not experienced before.

It was a sharing time. All during the day they were push, push, push, push, then they'd go home and cook dinner and do laundry and all the other things and so they were tired. But that was precious time that they could sit down with one another and laugh and talk and be. . . They were part of a circle of women, they learned about themselves, they learned about Canadians, they learned that people would listen to them, they learned ways of expressing themselves. (Catherine, 11. 1478-84)

The classes began to embrace all manner of learning concerns brought by the learners:

health problems, family issues, cultural adjustment questions, employment complaints, civic topics and citizenship preparation.

They had questions about you know, what's this pap smear thing we're supposed to get every year and why should we get a mammogram? And they, they brought personal things about their families and their fears, their concerns, so there was a great deal of mediating information for people. There was a great deal of information giving... about the community, about the country. (Catherine, 11 290-300)

Learning English, of course, gave workers the capability to negotiate directly with supervisors, and to access information sources. One worker described gaining confidence to negotiate days off with her supervisor: "Since I went to learn English that I learned, I know a lot more things. It helped me to become more ambitious" (Eun Jin, 1. 562). Workers also, according to the adult educators observing them over several years, developed some critical awareness and communicative competence that allowed them to confront what they judged unfair treatment by their supervisors: 
As people learnt that they had more rights, they stand up more to their supervisors. 'Listen, if you don't help me' - like talking to a supervisor - 'I can go and talk to management'. It was a learning process, and then they would teach their friends. They got more and more confident. (Annika, 11. 432-45)

Descriptions of this class space from the women and the instructors recall Welton's (1995) ideal of open, even democratically-styled participatory learning through dialogue: a space of confronting shared issues. Within this space women appeared to develop a sense of personal worth, rights, and the boundaries they could push to defend those rights. Clearly lines of action emerged from this space of solidarity. Yet the workers did not fundamentally move to a position of challenging or even questioning the plant closure and their impending job loss orchestrated by GWG, nor did they criticize management (in interviews). Overall their everyday learning through sociality 'on the line' appeared to converge with the communicative strategies, strengthened confidence and intimate connections nurtured in the English classes.

\section{CONCLUSION}

This discussion has explored processes of survival learning and possibilities for

critical learning in the workplace, with a focus on women, mostly new immigrants, working in the difficult conditions of the garment industry. Their negotiation of these conditions generated learning embedded in workers' everyday social interactions from which sprang closely connected networks. Even in the more formal English language classes, the women's learning emanated most powerfully through the informal sociality enabled there.

Within these networks women learned to survive difficult conditions. They learned to find their top speed possible while avoiding injury and mistakes, and to confront supervisors when necessary, taking small wins. A strong sociality of friendship, recognition of shared social 
position and interconnection, and mutual support reinforced a tacit worker solidarity. This sociality existed alongside and in some ways offset the fragmentation of work tasks, isolation and competition induced with focus on speed of production. Women developed a mutual dependence on one another both for personal income generation and for broader learning about health, family, and general survival as an immigrant. Beyond the infrequent instances of unionsponsored activity, sufficient small “outbreaks" of radical action occurred to indicate women's solidarity developing in everyday work on the line. Finally, despite its tiny size and the lack of obvious collective transformative or radical outcomes, the English language program at GWG opened sites where confidence and social connections were nourished, work conditions were discussed and actions for change considered.

All of these learning spaces generated forms of solidarity that helped forge a vital interdependent social network and collective identity. These learning spaces, while created within the factory, had escaped the control of both management and the union. Fluid and overlapping, they were subject neither to regulation nor appropriation for capital in the ways that Mojab and Gorman (2003) warn about. Yet within them and the solidarities emerging from them, some critical and even transformative learning occurred as women developed a sense of personal worth, collective identity, and strategies to survive and even resist oppressive conditions.

However, just as Mirchandani et al. (2002) found, there was not a clear either-or distinguishing transformative and reproductive learning, but unexpected continuities and disjunctures between them. While Mirchandani's study examines formal ICT learning of women immigrant garment workers, the practice-based shopfloor solidarities at GWG reflects similar blurring and complexity. Women obtained for themselves, within the limits of industrialized garment production, the best income and conditions they thought they could given their position as new immigrant women, some of visible minorities, who could not speak English. They were working 
with their friends: they created networks of close connections offering some refuge beyond their loads of family and factory labour, where they enjoyed a distinct identity. In these networks, as Lee (2006) and Sawchuk (2003) have also observed, emancipatory potential was released as women learned to exercise some control over their work and knowledge with minimal cost to their livelihood and safety. The sad ending to the story when the plant suddenly closed was not just about losing their jobs, but about the prospect of losing these solidarities that women had developed within the factory but outside the domains of managerial control: "All those people in my heart, I never forget them. . . that was my second home.” (Jia, 11. 700-703). We don't know exactly what happened to these solidarities as our study ended when the plant closed. However when we brought these participants together in a group to review our findings and the dramatic play we wrote based on these findings (Fenwick, in press), we learned informally that many were still meeting together at a city center for newcomers. As Thompson (1963) might have pointed out, they were continuing to make their own collective history: a history rooted in shared experience, values and above all feeling, not in an abstract category of 'immigrant' or 'garment worker'.

\section{Acknowledgements:}

I am grateful to the three anonymous reviewers of an earlier draft of this article who provided detailed comments that have strengthened the presentation considerably. Grateful thanks are also extended to the following organizations and research assistants who made important contributions to the larger project from which this study was drawn: Joan Schiebelbein, Catherine Cole Associates, Don Bouzek, Edmonton Community Foundation, Productions, Edmonton: A City Called Home, Ground Zero Provincial Archives of Alberta, Lan Chan Marples, and Melanie Wong. 


\section{REFERENCES}

Adams, F. with Horton, M. (1975). Unearthing Seeds of Fire: The Highlander Story. Blair.

Allman, P. (2001). Critical Education against Global Capitalism: Karl Marx and Revolutionary Critical Education. Westport, CT; London: Bergin \& Garvey.

Baldwin, P. (1990). The Politics of Social Solidarity. Cambridge: Cambridge University Press.

Church, K., Shragge, E., Fontan, J.M., \& Ng., R. (2000). While no one is watching: "Social learning” among people who are excluded from the labour market. In P. Sawchuk (Ed.), Researching Work and Learning Conference Proceedings (pp. 241-249). Calgary: University of Calgary.

Cunningham, P. (1993b). The politics of worker's education: Preparing workers to sleep with the enemy. Adult Learning, 5 (1), 13-14, 24.

Cunningham, P. (1993a). Let's get real: A critical look at the practice of adult education. Mountain Plains Adult Education Journal, 22 (1), 3-15.

D'Art, D. and Turner, T. (2002). The decline of worker solidarity and the end of collectivism? Economic and Industrial Democracy, 1, 7-34.

Dubinsky, D \& Raskin, A .H. ( 1977). A life with labor. New York: Simon and Schuster.

Ely, M. with Anzul, M., Friedman, T., Garner, D. \& McCormack Steinmetz, A. (1991). Doing qualitative research: Circles within circles. London: Routledge.

Fenwick, T. (2001). Socio-cultural Perspectives on Learning Through Work. San Francisco: Jossey Bass/Wiley.

Fenwick, T. (in press). Learning on the line: Voices of garment workers at GWG. Labour/Le travail.

Fenwick, T. (2004). Towards a critical HRD. Adult Education Quarterly, 54 (3), 174-192

Foley, G. (1999). Learning in Social Action. Leicester: NIACE.

Gannage, C. (1999). The health and safety concerns of immigrant women workers in the Toronto sportswear industry. International Journal of Health Services, 2, 409-429.

Heaney, Tom. 1996. Adult Education for Social Change: From Center Stage to the Wings and Back Again. ERIC monograph, Information series No. 365, Columbus Ohio.

Hodson, R., Welsh, S., Rieble, Jamisen, S., Sorenson, C., \& Creighton, S. (1993). Is worker solidarity undermined by autonomy and participation? Patterns from the ethnographic literature. American Sociological Review, 58 (3), 398-416

Hoffman, A.M. \& Hoffman, H.S. (1994). Reliability and validity in oral history: The case for memory. In J. Jeffrey and G. Edwall (Eds.), Memory and History: Essays on Recalling and Interpreting Experience (pp. 107-135). Lanham, Maryland: University Press of America.

Holst, J. (2001). Social Movements, Civil Society and Radical Adult Education. London: Bergin \& Garvey.

Howell, S. L., Carter, V.K., \& Schied, F.M. (2002). Gender and women's experience at work: A critical and feminist perspective on human resource development. Adult Education Quarterly, 52 (2), 112-127. 
Jackson, N. (1991). Skills Formation and Gender Relations: The Politics of Who Knows What. Geelong: Deakin University Press.

Lee, M. (2006). Critical adult learning of immigrant workers: A social network perspective. Proceedings of the Adult Education Research Conference.

Levine (Lorwin), L. L. (1924). The Women Garment Workers: A History of the International Ladies Garment Workers Union. New York: B.W. Huebsch.

Livingstone, D.W., \& Sawchuk, P.H. with Clara Morgan. (2004). Hidden Knowledge: Organized Labor in the Information Age. Boston: Rowan and Littlefield.

Mirchandani, M., Ng, R.,Sangha, J., Rawlings, T., \& Coloma-Moya, N. (2002). Ambivalent learning: Racialized barriers to computer access for immigrant contingent workers. Working paper, NALL project, OISE/UT .

Mojab, S. \& Gorman,R. (2003). Women and consciousness in the "learning organization": emancipation or exploitation? Adult Education Quarterly, 53 (4), 228-241.

$\mathrm{Ng}$, R. (1999). Homeworking: Dream realized or freedom constrained? The globalized reality of immigrant garment workers." Canadian Woman Studies, 3, 110-114.

$\mathrm{Ng}$, R. (2002a). Freedom for whom? Globalization and trade from the standpoint of garment workers. Canadian Women Studies, 4, 74-82.

$\mathrm{Ng}$, R. (2002b). Training for whom? for what? Reflection on the lack of training for immigrant garment workers. The Research Network for New Approaches to Lifelong Learning Working paper \#66, (Toronto, ON: OISE/UT, 2002). http://www.nall.ca/res/6Roxana\%20Ng.pdf

Portelli, A. (1998). What makes oral history different? In R. Perks \& A. Thomson (Eds.) The Oral History Reader (pp. 63-74). New York: Routledge.

Probert, B. (1999). Gendered workers and gendered work: Implications for women's learning. In Boud, D. \& Garrick, J. (Eds.), Learning in Work (pp. 98-116). London: Routledge.

Sawchuk, P.H. (2003). Adult Learning and Technology in Working-Class Life. Cambridge, UK: Cambridge University Press.

Schied, F. M. (1993). Learning in Social Context: Workers and Adult Education in Nineteenth Century Chicago. DeKalb, Illinois: LEPS Press.

Steedman, M, (1997). Angels of the Workplace: Women and the Construction of Gender Relations in the Canadian Clothing Industry, 1890-1940. Toronto, ON: University of Toronto Press.

Taylor, J. (2001). Union Learning: Canadian Labour Education in the Twentieth Century Toronto: Thompson.

Thompson, E. P. (1963). The Making of the English Working Class. London: Victor Gollancz.

Tyler, G. (1995). Look for the Union Label: A History of the International Ladies' Garment Workers' Union. New York: Sharpe

Vosko, L.F. (1993). The Last Threat: Analysis of the Apparel Goods Provisions in the North American Free Trade Agreement and the Impact nn Women. Ottawa: The Canadian Centre for Policy Alternatives. 
Welton, M.R. (1995). In defense of the lifeworld: A Habermasian approach to adult learning. In M. R. Welton, (Ed.), In Defense of the Lifeworld: Critical Perspectives on Adult Learning. New York: State University of New York Press, pp. 127-156.

Wolensky, K.C. (1996). Collective struggles - collective learning: A history of women garment workers and adult education. Proceedings of the Adult Education Research Conference. Tampa, FL: University of South Florida.

Wolensky, K.C., Wolensky, N.H.\& Wolensky, R.P. (2002). Fighting for the Union Label: The Women's Garment Industry and the ILGWU in Pennsylvania. PSU Press.

Zacharakis-Jutz, J. (1993). A design for democracy: The ethical element of adult education in the workplace. Thresholds in Education. 19 (1-2), 47-51. (ERIC No. EJ 466 905). 
Table 1: Participant Demographics (all names are pseudonyms)

\begin{tabular}{|c|c|c|c|c|c|c|c|}
\hline Name & Job(s) held & $\begin{array}{l}\text { Dates of } \\
\text { Employ } \\
\text { ment }\end{array}$ & $\begin{array}{l}\text { Country } \\
\text { of origin }\end{array}$ & Mingzhu & Seamstress & $\begin{array}{l}1979- \\
2004\end{array}$ & $\begin{array}{l}\text { Hong } \\
\text { Kong }\end{array}$ \\
\hline Lesley & Seamstress & $\begin{array}{l}1965- \\
1966\end{array}$ & Canada & \multirow[b]{2}{*}{ Mirela } & \multirow[b]{2}{*}{ Seamstress } & \multirow{2}{*}{$\begin{array}{l}1943- \\
1945 \\
1965- \\
1966 \\
\end{array}$} & \multirow[b]{2}{*}{ Italy } \\
\hline \multirow[b]{2}{*}{ Sarojni } & \multirow[b]{2}{*}{$\begin{array}{l}\text { Distributor; } \\
\text { Supervisor }\end{array}$} & \multirow[b]{2}{*}{$\begin{array}{l}1974- \\
2004\end{array}$} & \multirow[b]{2}{*}{$\mathrm{Fiji}$} & & & & \\
\hline & & & & \multirow[b]{2}{*}{ Eithne } & \multirow[b]{2}{*}{ Seamstress } & \multirow{2}{*}{$\begin{array}{l}1940- \\
1941\end{array}$} & \multirow[b]{2}{*}{ Canada } \\
\hline \multirow[b]{2}{*}{ Terry } & \multirow[b]{2}{*}{$\begin{array}{l}\text { Material } \\
\text { handler }\end{array}$} & \multirow[b]{2}{*}{$\begin{array}{l}1965- \\
2004 \\
\end{array}$} & \multirow[b]{2}{*}{ Canada } & & & & \\
\hline & & & & Dorottya & Seamstress & $\begin{array}{l}1938- \\
1946\end{array}$ & Ukraine \\
\hline Lihua & Seamstress & $\begin{array}{l}1981- \\
2004\end{array}$ & China & \multirow[b]{2}{*}{ Huahui } & \multirow{2}{*}{$\begin{array}{l}\text { Seamstress, } \\
\text { inspector }\end{array}$} & \multirow{2}{*}{$\begin{array}{l}1960- \\
1999\end{array}$} & \multirow[b]{2}{*}{ China } \\
\hline & & & & & & & \\
\hline Halina & Examiner & $\begin{array}{l}1981- \\
2004 \\
\end{array}$ & India & Yan & $\begin{array}{l}\text { Seamstress, } \\
\text { Instructor, } \\
\text { Supervisor }\end{array}$ & $\begin{array}{l}1969- \\
2004\end{array}$ & China \\
\hline \multirow{2}{*}{$\begin{array}{l}\text { Bhubinde } \\
\mathrm{r}\end{array}$} & \multirow[b]{2}{*}{ Seamstress } & \multirow{2}{*}{$\begin{array}{l}1975- \\
2004 \\
\end{array}$} & \multirow[b]{2}{*}{ India } & Huifang & Seamstress & $\begin{array}{l}1973- \\
2004 \\
\end{array}$ & China \\
\hline & & & & & \multirow[b]{3}{*}{$\begin{array}{l}\text { Operator, } \\
\text { single needle } \\
\text { machine }\end{array}$} & \multirow[b]{3}{*}{$\begin{array}{l}1939- \\
1942 \\
\end{array}$} & \multirow[b]{3}{*}{ Canada } \\
\hline Eun jin & Seamstress & $\begin{array}{l}1962- \\
1970 \\
\end{array}$ & China & & & & \\
\hline Hong & $\begin{array}{l}\text { Seamstress, } \\
\text { inspector }\end{array}$ & $\begin{array}{l}1963- \\
2002 \\
\end{array}$ & China & Helen & & & \\
\hline Nancy & $\begin{array}{l}\text { Seamstress, } \\
\text { receptionist }\end{array}$ & $\begin{array}{l}1988- \\
2004 \\
\end{array}$ & Canada & & $\begin{array}{l}\text { Seamstress, } \\
\text { instructor, }\end{array}$ & 1979 & \\
\hline & & & & Xiaofang & supervisor & 2004 & China \\
\hline Gioia & Seamstress & $\begin{array}{l}1980- \\
2004 \\
\end{array}$ & Italy & Daryna & $\begin{array}{l}\text { Seamstress, } \\
\text { supervisor }\end{array}$ & $\begin{array}{l}1957- \\
1997 \\
\end{array}$ & Hungary \\
\hline Annika & $\begin{array}{l}\text { Seamstress, } \\
\text { supervisor }\end{array}$ & $\begin{array}{l}1951- \\
1978 \\
\end{array}$ & Ukraine) & Emily & $\begin{array}{l}\text { Operator, } \\
\text { special } \\
\text { machines }\end{array}$ & $\begin{array}{l}1928- \\
1931 \\
\end{array}$ & Canada \\
\hline & & & & Beulah & $\begin{array}{l}\text { Presser, } \\
\text { cutter }\end{array}$ & $\begin{array}{l}1942- \\
1947 \\
\end{array}$ & Canada \\
\hline Boyka & Seamstress & 1968 & ovakia & & & & \\
\hline & Seamstress, & 1989 & & Emma & $\begin{array}{l}\text { Operator, } \\
\text { supervisor }\end{array}$ & & Canada \\
\hline Jia & cutter & 2004 & China & & & & \\
\hline
\end{tabular}




\begin{tabular}{|l|l|l|l|}
\hline Catherine & $\begin{array}{l}\text { Instructor, } \\
\text { director of } \\
\text { ESL } \\
\text { program }\end{array}$ & $\begin{array}{l}1987- \\
2004\end{array}$ & Canada \\
\hline & & & \\
& Instructor, & $\begin{array}{l}1989- \\
1996\end{array}$ & Canada \\
\hline Hermione & ESL & $1987-$ & \\
& Instructor, & 2004 & Canada \\
\hline Marg & ESL & $1990-$ & \\
\hline & Instructor, & 1995 & Canada \\
\hline
\end{tabular}

